\title{
The Narrative and Moral Discourse Regarding Marriage in Tobit
}

\author{
Boris Beck \\ Faculty of Political Sciences, University of Zagreb \\ Department of Journalism and Media Production \\ boris.beck@fpzg.hr
}

UDK 27-245;2-555

Original scientific paper

DOI: https://doi.org/10.32862/k.12.2.3

\begin{abstract}
Tobit was written around the third century B.C. It is considered canonical by the Catholics and the Orthodox believers, but not by Protestants and the Jews. The story is not historical but fictional, with a very dynamic narrative, containing numerous lessons in the spirit of the OT, particularly those relating to Deuteronomy theology. The central theme of the book is marriage and the ideal marriage is portrayed in terms of physical purity, struggling against lust, faithfulness, monogamy, and the permanence of the marriage covenant. It is pointed out in many places that love, fondness, and consideration are necessary for a successful marriage. Another important condition is the endogamy of marriage, so that the spouses would be able to keep and practice their faith more easily. And finally, prayer as the expression of trust in God is posited as the foundation of a marriage whose purpose transcends the erotic and procreative functions and emphasis is also placed on the importance of consecration. So in a fun way, Tobit offers a moral lesson which ties in with Biblical morality.
\end{abstract}

Key words: Book of Tobit, marriage, God, love, fondness 


\section{Introduction - the Canonical Status of Tobit}

In this paper, we will discover what Tobit says about marriage through storytelling and giving lessons and in the introduction we will offer a few remarks regarding the canonical status of the book and of its contents. Unlike the canonical books, which are considered to be inerrant and God-breathed sources of faith by all Churches, including the Jews, there are also books which have been written in Greek and after the times of the prophets, or perhaps they have only been preserved in Greek form alone, which is also the case with Tobit. The book had been included in the oldest OT translation, the Greek translation called the Septuagint, which was made between the $3^{\text {rd }}$ and $1^{\text {st }}$ centuries B.C. in Alexandria, as well as in the Latin translation, the Vulgate, which was made by Hieronymus in the $4^{\text {th }}$ century A.D.

Hieronymus referred to Tobit in the prologue of his translation of the Wisdom of Solomon, when he compared that book and Sirach: "Just as the Church reads the books of Judith, Tobit, and Maccabees but does not accept them into the Scripture canon, so can these two scrolls also be read for the building up of people, [but] not for establishing Church dogmas" (Gallagher 2007). Based on these words, we can assume that Hieronymus did not accept Tobit as a canonical book, but he did consider it valid for communicating moral lessons. In the Western Church, the book was included in the canon at the Synod of Rome in 382, and in the Eastern Church at the Quinisext Council in 692 (cf. Rapljenović).

At the Council of Trent in 1546, the Catholic Church established the OT canon at 45 books, Tobit included. "Under the influence Sixth from Sienna (152069) the Old Testament books which have been left out of the Talmud were dubbed 'deuterocanonical', while those which have been included in the Talmud and the Septuagint were dubbed 'protocanonic", however, "In German, Hungarian, and other Protestant translations from the $16^{\text {th }}$ century we can still read all the deuterocanonical books, but as of $17^{\text {th }}$ century we no longer find any of these texts" (Lökös 2002, 38). Even Martin Luther's German translation of the Scriptures includes the deuterocanonical books, but calls them apocryphal and includes Luther's note: "These books are not considered equal to the Scriptures, however they are still helpful and good for reading" (Evangelical Lutheran Synod), which is an obvious repetition of Hieronymus' stance. ${ }^{1}$ Unlike Luther, The Westminster Creed from 1646 resolutely denies any kind of inspiration in the apocryphal

1 In order to avoid a misunderstanding in terminology, we must emphasize that what is considered apocryphal among Catholics are those books "which the protestants refer to as 'pseudigrapha' - books which are similar in character and date as the apocryphal books, but were never considered canonical." (Biblical Manual 1989: 461). 
books, claiming that "they have not been divinely inspired, they are not part of the canon and the Scriptures, and thus have no authority for the Church, so they cannot be approved or used in any way, other than human writings" (The Confession of Faith of the Assembly of Divines at Westminster).

A similar position toward the deuterocanonical books as that of Hieronimus and Luther is held by today's Jews: even though the "Rabbis haven't included them into their sacred writings," those books "contain history, wisdom, morality, poems, and stories" which provide insight into "the life of Jews, their outlook, and their customs" (Da-Don 2004, 501). A new incentive for studying Tobit was sparked by the discovery of segments from it in the Qumran writings, three of which are in Aramaic, and one in Hebrew, which proves that Tobit was read and guarded among the Jews of antiquity, and it also points to the fact that it was probably written on Israeli soil (cf. Dimant 2017). ${ }^{2}$

\section{The Story and the Lesson}

Tobit has a "moral goal," i.e. "it attempts to convey the moral and religious lessons to the future generations in the form of drama, art, and fiction" (Župarić 2012, 712). Therefore, this is not a historical story but a literary one which is "able to transcend the limits of our immediate experience" and to create "a world of its own which works according to its logic" (Peleš 1989, 194). In other words, Tobit is organizing a fictional plot in order to affirm a certain ethics within its structure, where the fictional nature does not automatically imply that it is also not ethical.

In a very dynamic narrative, we follow the life of a married couple, Tobit and Anna, from the tribe of Naphtali. They live with their son, Tobias ${ }^{3}$ in Assyria and Nineveh in exile, but as godly people (Tob. 1). Due to an accident, the father goes blind and the family descends into poverty (Tob. 2), after which the father begins to pray (Tob. 3). In the same chapter we find out that in Ecbatana, there is a girl

2 Due to the parallels with another deuterocanonical/apocryphal book, i.e., Sirach, it is considered that Tobit was written after the time of Ezra - after the building of the Second Temple, but before the building of Herod' Temple. For example, Tob 4:10 and 12:8-9 are identical to Sir 3:30, while Tob 4:17 has a parallel in Sir 12:4-5, due to which we can conclude that both Sirach and Tobit were written at the same time: not before the 3rd century B.C. (cf. Howell Toy 19011906).

3 In the original texts, both the father and the son bear the same name: Tobit, in Aramaic, and Tobias in the Greek texts, which is the source of the difference in names in various translations. In order to avoid any confusion, the translator of the Zagreb Bible named the father Tobit, and the son Tobias. 
named Sarah who has an unusual problem: the demon Asmodeus keeps killing her husbands on the wedding night so she continually lives in misery, both as a virgin and a widow at the same time; and she's praying to God at the same time as Tobit Senior, and God decides to answer their prayers. In chapters 4 and 5, along with a wealth of moral instructions, Tobit sends his son to Rages to get the money, accompanied by the angel Raphael, who introduced himself to them as a common man. In chapter 6 , on his way through the desert, Tobias catches a miraculous fish whose internal organs have exorcismal and medicinal properties, and Raphael talks him into marrying Sarah. After the wedding (Tob. 7), the wedding night prayer (Tob. 8) and the feast (Tob. 9) - which is the "center point of the entire book" (Zovkić 1993, 114) - Tobias and Sarah go to Nineveh (Tob. 10), where the son heals the father (Tob. 11). In the end, the angel reveals his identity (Tob. 12), and the father says a prayer (Tob. 13) and gives his son some final instructions before he dies (Tob. 14).

The reader's attention is drawn by the love plot in which the important dynamic motifs are fantastical, such as the actions of angels and demons (particularly in Tob. 2 and 12), as well as using fish entrails for the purpose of healing and exorcism (Tob. 8 and Tob. 11). Frye categorizes this type of narration as the romantic literary form: its key ingredient is adventure, which means that "romance is in its nature a sequenced and procedural form," while its content is "a successful quest," which consists of "a perilous journey," "decisive struggle" and "the hero's exaltation" $(2000,212-213)$ - where the "goal of the journey was not only for the young man to bring back the family money, but that he would also grow into the responsibility of a grown man" (Zovkić 1993, 114). However, in mentioning the demon Asmodeus, Dimant (2017) sees an important sign for including Tobit into Aramaic literature. According to this author, some other links are the obligation of burying the dead (Tob. 1:17-19; 2:3-8; 12:12) and various other halachas that are linked to tithing among the residents of Qumran (1:6-8). Dimant also sees endogamy as one of the typical themes from Israelite literature, because the father took a wife from his own family $(1: 10)$ and is advising his son to the same (4:12-13). Since the wedding is the central theme in Tobit, we notice many related halachas: "There are several Talmudic rules about the kidushin (engagements), ketubah, and the wedding. Those halachas come from the description of the wedding of Tobias and Sarah bat Reuel" (Da-Don, 2004, 502). In this way, the topics of the young people getting to know each other and their marriage develops as a combination of an exciting story and various bits of advice about it - using the example of the "historic novel" to show how merciful believers receive the help from "the God who saves" (Deslaers according to: Zovkić 113). 


\section{Marriage in Tobit}

\section{Purity and Monogamy}

In Tobit, the researchers have recognized the OT theology, particularly that from Deuteronomy, which is seen as "eating the food (Tob. 1:11), in the obligation to bury the dead (Tob. 1:12-20; 2:38), in solidarity with the needy" (Tob. 4:711:16) (Župarić 2012, 716). Furthermore, the father's "faithfulness to God's law was particularly seen in his penitential practices, in his noble attitude towards the servants in the sanctuary, in his love for the Temple (Tob 1:4s; 13:10s; 14:4s), and the monogamous marriage" (ibid. 714). Since the wedding and marriage are at the center of interest in Tobit - both in terms of narration and in terms of ethics - we will go on to explore what sort of marriage ideal is being offered here.

One of the characteristics of marriage, as recognized in scientific literature, is monogamy. While polygamy is mentioned in the Bible during the times of patriarchs, "the later Biblical writings, and particularly the wisdom books, no longer mention it," assuming a monogamous marriage, and "this new view of marriage finds its best expression in Tobit" (Barišić 1982, 202). Since monogamous marriage is never explicitly mentioned in Tobit, the author draws his conclusion implicitly: Tobit Senior and Anna are the only spouses and there is no indication that Tobit ever had another wife or a concubine.

Furthermore, as far as the young couple is concerned, Tobit emphasizes the importance of physical purity. That is why Sarah in her prayer is able to say this with a pure soul, "You know, O Lord, that I'm still a virgin; I have never been defiled by a man. Never have I disgraced myself or my father's name, as long as we have lived in this land of exile" (Tob. 3,14-15, GNT). ${ }^{4}$ Thus, physical purity is not just an individual's personal matter but it also has to do with the family; i.e., Sarah's relationship with her father obliges her to remain pure. The same goes for young Tobias, whose father also tells him to steer away from all lust (Tob. 4:12). Lust is not explained in any detail but it is known that debauchery and adultery were frequently forbidden in the Old Testament (Ex 20:14; Ex 6,24-32) because the Bible holds that "sexual satisfaction finds its legitimate expression only in the confines of the marriage" (Rock 2003, 127). This is because God "is maintaining the highest level of morality which his will requires from the creation," and therefore "sexual licentiousness profanes the holy God" (McKenzie 1980, 197). In other words, physical purity does not only bind Tobias and Sarah in their relationship with their parents but also in their relationship with God, because there

4 All Croatian quotes from Tobit have been taken from the translation by Mate Zovkić published in 2007 in the Gordogan magazine, as stated in the bibliography; other Scripture quote have been taken from the Zagreb Bible. 
is a relationship of reciprocity between the creation and the Creator: God sets standards for behavior which he himself also clings to and people cling to such behavior out of love. The demands placed before Sarah and Tobias are necessary for the quality of their relationship with God because that relationship is based in morality.

We can conclude that Tobit accepts Jewish rules as upheld by Deuteronomy that in its context young men and young women are forbidden to have sexual relations outside of marriage, and even married people are forbidden from having sex outside of marriage and that marriage is monogamous.

\section{Prayer, Man, and Marriage}

At the beginning of Sarah and Tobias' marriage - along with the conditions that the betrothed should belong to the same family (and consequently to the same people and faith) and that they should be sexually pure - there is also one other important condition: prayer. Raphael warns young Tobias of the importance of prayer beforehand, "But before you consummate the marriage, both of you must get up and pray for the Lord in heaven to be merciful to you and to protect you" (Tob. 6:17). The prayers in Tobit "are uttered by both men and women" and "at key points of the book" and "they have great weight and value" (Župarić 2012, 726). ${ }^{5}$ It is therefore not unusual that, at the crucial point of the plot - before Tobias and Sarah were able to consummate their marriage union, an act which had up until that point been interrupted by the demon who would murder the husband - the newlyweds started praying as described in Tob. 8:1-9: after the ceremonies and the festivities were finished, the members of the household went out and closed the newlyweds' room after them; Tobias got up from his bed and said to Sarah, "Get up, dear. Let's pray for the Lord to be merciful and to protect us." Sarah then got up and they prayed for their health together:

"You said, it is not good for man to live alone. I will make a suitable helper for him. Lord, I have chosen Sarah because it is right, not because I lusted for her. Please be merciful to us and grant that we may grow old together. Then they both said Amen and went to bed for the night."

Sexuality, together with its procreative role, is here replaced with prayer in order to invoke "an act of mercy" (Zovkić 1993, 114), showing the precedence of supernatural over the natural.

Tobias' prayer to "grow old together" with Sarah shows "the seriousness of the marriage program they've planned for themselves" and that they are "starting their life together, not only as a result of current affections and the need 
for another person's closeness, but they're also looking at the whole picture and the ending of human life" (Bilić). The conditions of monogamy and premarital and marital purity are thus also joined by the condition of the permanence of marriage - which is explicitly explained in the last chapter of Tobit: the couple lived to see old age together with their children. Just like with the condition of monogamy, the condition of the permanence of marriage is also portrayed by a careful image of the aging married couple, Tobit and Anna. It is most certain that, connected with the monogamy that was mentioned in the previous passage, is the fact that the newlyweds quoted Genesis in the wedding night prayer, ${ }^{6}$ which is a reminder of the fact that "marriage, as well as Sabbath, was established in Eden" (Rock 2003, 125) and that wedding is a fulfillment of God's will, i.e., for Tobias and Sarah marriage is "the fulfillment of what God has given [them] based on his divine judgment" (Bilić). The importance of prayer - both throughout Tobit, as well as in the very act of wedding, which is the center point of the book - shows that relationship with God is crucial for man and that all human relationships, including marriage, can and must be observed only within the relationship to the Creator. The fact that the relationship between man and God should be pure, exclusive, and also permanent is set as a prerequisite for marriage.

\section{Feast and Blessing}

The ceremony of marriage is still very important all over the world, and it was also important in Biblical, i.e., post-Biblical times, if we follow the understanding that Tobit was written after the canon had already been defined. According to Rock (126), the Biblical wedding ceremony was preceded by selecting the bride and arranging the marriage, which was followed by gift-giving (cf. Isaac's gift to Rebecca in Gen. 24) and the engagements (Deut. 22:23-27). The wedding was accompanied by a feast with family and friends as guests (Judges 14:11, Gen. 29:27), and the "sexual intercourse would mark the pinnacle of the wedding and the ending of the wedding ceremony" (Rock 2003, 126), while the bride's virginity would be proven with a bloody sheet, if necessary (Deut. 22:13-21).

In Tobit, the bride was not chosen by the groom's family, but by the companion - the angel Raphael; however, the bride has been chosen fully according to the father's instructions, and also Raphael was the young man's caretaker as authorized by the father. Also, the gifts have not been given nor were the engagements over - which is understandable from the context of the story, i.e. that the bride was avoided by everyone and that the bride's family was in a hurry so that Tobias would not change his mind. The feast was held after all - the wedding guests had

6 "For this reason a man shall leave his father and mother, and be joined to his wife; and they shall become one flesh" (Gen 2:24, NASB). 
dinner at the very wedding day (Tob. 8:9), and when they saw that the groom survived, the celebration was extended to two weeks (11:9); the wedding party was then joined by Tobit Senior's business associate, Gabael from Ragesa (Tob. 9:6), thus symbolically stepping in for the absent father.

The wedding itself and the welcoming of the bride have been described very nicely. Raguel called his daughter Sarah, took her by the hand, and gave her to Tobias with these words, "I will give her to you just as the Law of Moses commands"; Take her safely with you to your father's house"; and "May the God of heaven give you a happy life together" (Tob. 7:12-13) - it is possible that those words were part of the actual wedding ceremony. The welcome offered to the newlyweds in Nineveh was also a warm one, and these are the words of Tobit Senior:

"Welcome, daughter! Praise God for bringing you to us, my daughter. May God bless your father, as well as you and my son Tobias. Welcome to your new home. May you always be blessed with good health and happiness. Come in, daughter!" (Tob. 11:17).

There is warmth radiating from these words, and they can serve as example even today, because the newlyweds are leaving their families and still have not established their own and they sure need understanding in those moments. "The perspective offered for marriage and family by this Bible book is a blessing and a great joy" (Bilić) - so adding to the already recognized characteristics of marriage there are two more, equally important: unification and joy, both of the newlyweds and of their families.

\section{Love and Commitment}

Young Tobias was expected to become a father and thus continue the family line, "Remember that Noah, Abraham, Isaac and Jacob, our earliest ancestors, all married relatives. God blessed them with children, and so their descendants will inherit the land of Israel" (Tob. 4:12). With these words, the father encouraged his son. ${ }^{7}$ The people of God were being renewed in this way, which is confirmed by another of Tobit Senior's instructions, "Bring up your children to do what is right. Teach them that they must give to the poor and must always remember to praise God with all sincerity" (Tob. 14:9).

Of course, without the mother there would be no children, so she deserves all possible respect, "...show respect to your mother. Remember, she risked her life to bring you into this world, so try to make her happy and never do anything that would worry her" (Tob. 4:3-4). The way young Tobias was taught to treat his mother in his youth, he will now treat his wife once she has become a mother herself.

7 These words echo the ancient commandment to "Be fruitful and multiply" (Gen. 1:28, NASB) and the deep sentiment that "children are a gift of the LORD" (Ps. 127:3, NASB). 
Thoughtfulness and considerateness are generally important for the writer of Tobit, so the newlyweds are also expected to be gentle and respectful of each other. "Marriage is no longer just a vehicle for childbirth(...); more and more emphasis is placed on the personal relationship between the partners; the relationship of love" (Barišić 1982, 202). Tobit places great social demands before the newlyweds, but it also emphasizes the importance of mutual closeness, and it particularly cites the most important element of marriage, which is deep and honest love:

"Tobias listened very carefully to what Raphael had to say. He knew that Sarah was a relative on his father's side of the family. He began to fall in love with her and looked forward to marrying her" (Tob. 6:17). "In that moment true love for Sarah was born in his heart," but the "phenomenon of determined sympathy and infatuation (...) doesn't stop at the whimsical attractiveness of appearances and looks, but is hiden deep within a person" (Bilić).

Physical love must always be paired with spiritual love. And while Sarah and Tobias Jr. were at the beginning of their life's journey and we do not know what will happen to them in the first part of the book, in Tobit we have another married couple to look up to: Tobit and Anna. Their relationship is not without strains, but it is filled with respect. Since Tobit had gone blind, he was no longer able to provide for his family and he took it very hard, "...my wife Anna had to go to work, so she took up weaving, like many other women. The people she worked for would pay her when she delivered the cloth." (Tob. 2:11-12), says Tobit about his hard-working wife. Thus, Anna is portrayed as an excellent wife, like the one described in Proverbs 31, that wakes up before the rest of the household and provides for all their needs.

However, in the moments when Anna thought that her husband was wrong and that it was not wise to send off their son on a dangerous journey, she did not hesitate to confront him. In Tobit we read that the young man's mother cried and told her husband,

"How could you send my son away like this? she complained. He's our only means of support. Who will take care of us now? Is that money so important to you that you are willing to risk your own son's life to get it back? Why can't we be content to live on what the Lord has given us? (Tob. 5:17-19).

Her husband is not agitated by her words; instead, he calms her down with these words (12:21-23), "Calm down, Tobit said to her. He will get there and back safely, and with your own eyes you will see him return home safe and sound. Now stop worrying about them, dear. A good angel will go with Tobias. He will have a successful journey." Tobit goes on to say, "At that, Anna calmed down and stopped crying," which must be one of the most endearing scenes in the whole of Tobit's book. 
"Thus we are given an interesting blueprint which may seem a little foreign to the modern ear: first comes love, then come spirituality and prayer, and then come physical closeness and tenderness. All three steps in this trefoil are important: the three steps to fellowship" (Bilić). We can look at the elder couple and see what this fellowship looks like.

\section{Spiritual and Material Well-Being}

Along with numerous and extensive spiritual instructions, Tobit does not ignore the material side of human life because "the institution of marriage has been influenced by social and economic circumstances" (Barišić 1982, 202). Tobit's book reminds the newlyweds that they ought to live modestly and honestly, so among other pieces of advice is included this one, "Such pride leads to terrible frustration and ruin, just as laziness brings on severe poverty and causes starvation" (Tob. 4:13). In this way, godliness is seen as a prerequisite for both spiritual and material well-being, "Take advantage of every opportunity to praise the Lord your God. Ask him to make you prosper in whatever you set out to do" (Tob. 4:19). It is significant to note that love and belonging to the family are mentioned together, and that Tobias is expected to "marry a woman of our tribe" (Tob. 4:12). This is surely because it is the best way for him to keep his godliness and obey God's commandments. Pride is a transgression "of the moral order in relation to personal and social life," and in the specific situation it would mean, "rejecting his father's instructions regarding the choice of his life partner," which is why Tobit's book adamantly insists on endogamy which "aims at religious purity" (Župarić 2012, 725). These words conclude the instructions on marriage as something that is hard to establish and even harder to maintain but is worth all the trouble - and those who are faithful to God will be "followed by a good angel," as is promised by this charming and instructive book which has been attracting and inspiring readers for more than two millennia.

\section{Conclusion}

Tobit was probably written during the middle of the $3^{\text {rd }}$ century B.C., and the discoveries of the Qumran show that it was read and revered among the Jews during the Antiquity, making it likely that it was written somewhere in Palestine. It is considered to be canon by Catholics and Orthodox believers, while believers coming from Protestant heritage include it in apocryphal writings, and Jews into the so-called removed books which are not considered inspired, but they do have value because they provide insight into the lives and thoughts of believers in the past; particularly, in Tobit it "states that Tobias took Sarah according to the faith of Moses, that they prayed the blessings and wrote a ketubah, as prescribed by the 
Talmud, and the custom remains until this day" (DaDon 2004, 502).

In Tobit we read that God sends the angel Raphael to aid some people in trouble who called upon God's name: Raphael would lead young Tobias through the perilous desert, help him outwit the demon and marry Sarah, without forgetting the financial side of the endeavor nor his father's blindness. So this was God's intervention and the religious lesson is given under the guise of a dramatic story, "While telling an interesting tale about Tobias, the author also provides religious instruction. The Jewish values and practices are communicated to the listener in the form of an adventurous story" (Rapljenović). Tobit is rich with instructions which fit into the OT theology, particularly the elements from Deuteronomy, so it is easy to see why Hieronymus or Luther considered it a useful read.

The central theme of the book is the marriage of two young people, but the emphasis was placed not so much on the romantic and physical part, but on its spiritual essence, because "marriage has a religious character and redemptive power" (Barišić 1982, 202). Marriage, as understood in Tobit, is such a covenant between two people which must be exclusive and permanent in order to improve the godliness of the married partners: in Tobit, marriage is "a powerful experience shared by two persons, and it is sacred. It must be monogamous (Tob. 8:6), from the tribe of the fathers, and prepared through an untainted life (Tob. 3:14; 4:12), arranged by God's will (Tob. 8:7) and blessed by the parents (Tob. 7:12; $8: 17 ; 10: 13$ ) (Župarić 2012: 725). It is from this aspect that we need to understand the endogamous character of the marriage, because that was the only way to keep the commitment to the Jewish faith.

Furthermore, the key elements of marriage are joy, mutual support, consideration, love, and contemplation, "The wedding encounter of the newlyweds Tobias and Sarah is permeated with meditation and prayer (...) and the partners mediate an atmosphere of healing to one another" (Deselaers according to Zovkić 1993: 114). Here we finally see that healing of the father's blindness and saving Sarah from demons are just stories of faith's triumph over unbelief, righteousness over sin, and that the purpose of marriage is keeping the virtue of faith, hope, and love. The writer of Tobit uses the example of Tobias and Sarah to show that their marriage is not only oriented on themselves and their children - although care is taken of the spouse's happiness and the well-being of their offspring - but that the core mission of the marriage is maintaining and achieving godliness.

\section{Bibliography}

Barišić, Marin. 1982. „Biblijsko poimanje braka“. Crkva u svijetu, Vol. 17, No. 3. 198-209.

Biblija. Stari i Novi Zavjet. Zagreb, Kršćanska sadašnjost 
Biblijski priručnik. Mala enciklopedija. 1989. Ur. David i Pat Alexander. Zagreb, Duhovna stvarnost

Bilić, Niko. „Tobija i Sara“. http://amdg.ffdi.hr/tobija.htm

DaDon, Kotel. 2004. Židovstvo: život, teologija, filozofija. Zagreb, Profil

Dimant, Devorah. 2017. „Aramaic Tobit at Qumran“. http://www.ancientjewreview.com/articles/2017/3/22/aramaic-tobit-at-qumran (accessed 27.04.2017.)

Evangelical Lutheran Synod, http://els.org/resources/answers/apocrypha/ (accessed 27.04.2017.)

Frye, Northrop. 2000. Anatomija kritike. Zagreb, Golden marketing

Gallagher, Ed. 2017. „Jerome’s Prologue to the Books of Solomon“. http://sanctushieronymus.blogspot.hr/2007/12/jeromes-prologue-to-books-of-solomon.html (accessed 27.04.2017.)

Howell Toy, Crawford. 1901-1906. „Tobit, Book of“. The Jewish Encyclopedia. New York, Funk and Wagnalls. http://www.jewishencyclopedia.com/ articles/14422-tobit-book-of (accessed 27.04.2017.)

Lőkös, István: 2002. „Fabulae i apocrypha: estetska determinacija u starozavjetnoj Knjizi o Juditi“. Colloquia Maruliana, XI, 37-44

Knjiga o Tobiji. 2007. prev. Mato Zovkić. Gordogan, 11-14, 71-77.

McKenzie, John L. „Starozavjetna biblijska teologija“ u: Biblijska teologija Staroga i Novoga zavjeta. Zagreb, Kršćanska sadašnjost, 141-179.

Peleš, Gajo. 1989. Priča i značenje. Zagreb, Naprijed

Rapljenović, Robert. „Knjiga o Tobiji“. http://amdg.ffdi.hr/tobija_rapljenovic. pdf (accessed 27.04.2017.)

Rock, Calvin B. 2003. „Brak i obitelj“. Biblijski pogledi, Vol. 11, No. 1-2, 123-152.

The Confession of Faith of the Assembly of Divines at Westminster. file://C:/

Users/boris.beck/Desktop/The\%20Confession\%20of\%20Faith.html (accessed 27.04.2017.)

Zovkić, Tobija. 1993. „Duhovni komentar Knjige o Tobiji. (prikaz knjige P. Deselaers; Das Buch Tobit, Geistliche Schriftlesung 11, Patmos Verlag Dusseldorf 1990, 247 str). Crkva u svijetu, Vol. 28, No.1, str. 113-115.

Župarić, Drago. 2012. „Moralni naglasci u Knjizi o Tobiji“. Bogoslovska smotra br. $82,3,711-729$.

Translated from Croatian to English by Davor Edelinski 


\title{
Boris Beck
}

\section{Narativ i moralni diskurs o braku u Knjizi o Tobiji}

\begin{abstract}
Sažetak
Knjiga o Tobiji napisana je oko 3. st. pr. Kr. Kanonskom je smatraju katolici i pravoslavni, a protestanti i Židovi ne. Pripovijest nije historijska, nego fiktivna, vrlo dinamične fabule, pri čemu sadrži brojne pouke u starozavjetnom duhu, napose deuteronomističke teologije. Brak joj je središnja tema, a ideal braka predstavlja tjelesna čistoća, borba protiv požude, vjernost, monogamnost i trajnost ženidbenog saveza. Na više mjesta prikazuje se kako su ljubav, privrženost i obzirnost nužni za uspješan brak. Važan je uvjet i endogamnost ženidbe, kako bi supružnici lakše sačuvali i prakticirali vjeru. Na koncu se molitva - kao izraz povjerenja u Boga - postavlja kao temelj braka čija svrha nadilazi erotsku i prokreativnu funkciju, a ističe se važnost posvećivanja. Knjiga o Tobiji tako u zabavnom obliku čitatelju nudi moralnu pouku koja se nadovezuje na biblijski moral.
\end{abstract}


